\title{
Decidual expression and regulation of fatty acid desaturase 3 during mouse decidualization
}

\author{
Shuai Lin¹, Yu-Yuan Zhu ${ }^{1}$, Wei Hu , Yan Yang ${ }^{1}$, Jia-Mei Luo ${ }^{1}$, Shi-Jun Hu² and Zeng-Ming Yang ${ }^{1}$ \\ ${ }^{1}$ College of Veterinary Medicine, South China Agricultural University, Guangzhou, China and ${ }^{2}$ Institute for \\ Cardiovascular Science, Soochow University, Soochow, China
}

Correspondence should be addressed to Z-M Yang; Email: zmyang@scau.edu.cn

\begin{abstract}
Decidualization is required for the successful establishment of pregnancy in rodents and primates. Fatty acid desaturase 3 (Fads3) belongs to the fatty acid desaturase family, which is a crucial enzyme for highly unsaturated fatty acid biosynthesis. However, the expression, regulation and function of Fads3 during early pregnancy in mice are still unknown. In this study, we examined Fads3 expression, regulation and function during mouse decidualization. The expression of Fads 3 is detected in the subluminal stromal cells at implantation site on day 5 of pregnancy, but not at inter-implantation site and in day 5 pseudopregnant uteri. Compared to delayed implantation, Fads3 is strongly expressed after delayed implantation is activated by estrogen treatment. From days 6 to 8, Fads3 mRNA signals are significantly detected in the decidua. In ovariectomized mice, estrogen significantly stimulates Fads3 expression. However, estrogen has no effect on Fads3 expression in ovariectomized ERo-deficient mice, suggesting that estrogen regulation on Fads3 expression is ER $\alpha$ dependent. When ovariectomized mice were treated with progesterone, Fads3 expression is significantly increased by progesterone. Progesterone stimulation on Fads3 expression is also detected in cultured stromal cells, which is abrogated by RU486 treatment. These data indicate that progesterone upregulation on Fads3 expression is progesterone receptordependent. Fads3 knockdown by siRNA reduces in vitro decidualization of mouse stromal cells. Taken together, Fads3 may play an important role during mouse decidualization.

Reproduction (2018) 156 429-437
\end{abstract}

\section{Introduction}

Embryo implantation and decidualization are essential for the establishment of pregnancy in rodents and primates. After embryo implantation occurs, the stromal cells surrounding the implanting blastocyst begin to proliferate and differentiate into large, round decidual cells. This process is known as decidualization. Impaired decidualization can lead to adverse outcomes such as implantation failure and miscarriage (Carson et al. 2000). In mice, decidualization is stimulated by the blastocyst and can also be induced by scratching the endometrium or intraluminal injection of oil (Gellersen \& Brosens 2014). The establishment of pregnancy is orchestrated by ovarian estrogen and progesterone, which are crucial for implantation and decidualization in mammals (Dey et al. 2004). The physiological effects of estrogen and progesterone are mediated by binding to their cognate receptors, estrogen receptors (ER) and progesterone receptor (PR). ER $\alpha$-knockout mice show ovarian dysfunction and estrogen insensitivity of the uterus (Schomberg et al. 1999). PR-knockout mice are infertile due to the defects in embryo implantation and decidualization (Mulac-Jericevic et al. 2000). However, the molecular mechanism during decidualization is still unclear.

Highly unsaturated fatty acids (HUFA), especially arachidonic acid (20:4n-6) and docosahexaenoic acid (DHA, 22:6n-3), are metabolically required for many developmental processes. The dysfunction in the metabolism of HUFAs will result in cardiovascular disease, cancers and diabetes (Lee et al. 2016). HUFA, a long-chain subgroup of poly unsaturated fatty acids, can be biosynthesized from linoleic acid (LA, 18:2n-6) and $\alpha$-linolenic acid (ALA, 18:3n-3) (Zhang et al. 2017).

Fatty acid desaturases are essential enzymes that mediate the introduction of double bonds at specific positions in a long-chain fatty acid (Nakamura \& Nara 2004). Fatty acid desaturase 1 and 2 (FADS1 and FADS2) catalyze the biosynthesis of HUFA. FADS1 introduces a double bond at the $\Delta 5$ position of 20-carbon fatty acids (Kothapalli et al. 2016). FADS2 catalyzes the introduction of a double bond at the $\Delta 4, \Delta 6$ or $\Delta 8$ position, which is a rate-limiting step for the biosynthesis of eicosapentaenoic acid (DHA) (Park et al. 2016). Arachidonic acid is the precursor for the biosynthesis of prostaglandins, prostacyclins and leukotrienes (Lee et al. 
2016). Arachidonic acid can be synthesized from LA utilizing three enzymatic steps. Two of these steps are catalyzed by FADS1 and FADS2 (Hester et al. 2014). FADS3 is the third member of the FADS gene cluster and evolutionarily results from a gene duplication event with Fads 1 and Fads2 (Zhang et al. 2017). However, FADS3 function remains elusive. Based on the 62 and $70 \%$ sequence homology with Fads 1 and Fads2, Fads3 may be a new fatty acid desaturase (Blanchard et al. 2011). Recent data indicate that Fads3 plays a role during early development as an enhancer of HUFA biosynthesis and/ or regulation (Zhang et al. 2017).

Based on our SAGE analysis, Fads3 expression is significantly higher at the implantation site than interimplantation in mouse uterus (Ma et al. 2006), suggesting a putative involvement of Fads3 in early pregnancy. However, the expression, regulation and function of Fads3 in mouse uterus during early pregnancy are still unknown. In this study, we showed that Fads3 is strongly expressed in mouse decidua and upregulated by progesterone.

\section{Materials and methods}

\section{Animal treatments}

Mature CD-1 mice were caged in a temperature- and lightcontrolled environment ( $12 \mathrm{~h}$ of light and $12 \mathrm{~h}$ of darkness) with free access to regular food and water. All animal procedures were approved by the Institutional Animal Care and Use Committee of South China Agricultural University.

Adult female mice were mated with fertile or vasectomized males to induce pregnancy or pseudopregnancy (day 1 is the day of vaginal plug). On days 1-4, pregnancy was confirmed by flushing embryos from oviducts or uterus. On day 5, the implantation sites were visualized through intravenous injection of $0.1 \mathrm{~mL}$ of $1 \%$ Chicago blue dye (Sigma Aldrich) in saline.

Delayed implantation was induced by ovariectomizing pregnant mice at 08:30-09:00 on day 4 of pregnancy. Progesterone was subcutaneously injected ( $1 \mathrm{mg} / \mathrm{mouse}$, Sigma Aldrich) from days 5 to 7 . Estradiol- 17 ( $25 \mathrm{ng} /$ mouse, Sigma Aldrich) was given to progesterone-primed delayed mice to activate blastocyst implantation on day 7 of pregnancy. On day 8 of pregnancy, the mice were killed to collect uteri after estrogen treatment. The activation of implantation sites were identified through intravenous injection of $0.1 \mathrm{~mL}$ of $1 \%$ Chicago blue dye. Delayed implantation was confirmed by flushing blastocysts from one horn of the uterus on day 8 of pregnancy and uteri were collected for further analysis.

To induce the artificial decidualization, pseudopregnancy mice were infused $10 \mu \mathrm{L}$ of sesame oil (S3547; Sigma Aldrich) into one uterine horn on day 4 , whereas another uninjected horn served as a control. The uteri were collected on day 8 of pseudopregnancy.

To determine the effects of steroid hormones on Fads3 expression, the ovariectomized mice rested for 2 weeks to eliminate circulating ovarian steroids. Mice were injected subcutaneously with estrodiol- $17 \beta \quad(100 \mathrm{ng} /$ mouse $)$ or progesterone $(1 \mathrm{mg} /$ mouse). The control mice were injected subcutaneously with sesame oil $(100 \mu \mathrm{L} /$ mouse). Mice were killed and the uteri were collected after the hormone injections for $24 \mathrm{~h}$.

To estimate whether Fads3 expression was ER $\alpha$ dependent, WT or ER $\alpha$ knockout (ER $\alpha \mathrm{KO}$ ) mice were ovariectomized and rested for 2 weeks and then injected subcutaneously with estrodiol- $17 \beta$ (100 ng/mouse). The control mice were treated with sesame oil as vehicle. The uteri were collected after the estrodiol-17 injections for $24 \mathrm{~h}$.

\section{In situ hybridization}

Total RNAs from mouse uteri on day 5 of pregnancy were reverse transcribed and amplified with the specific primers for mouse Fads3. The amplified fragment of Fads 3 was cloned into pGEM-T plasmid and verified by sequencing. The primers of T7 and SP6 were used to amplify Fads3 fragment from the pGEMFads3 plasmids. Digoxigenin-labeled antisense or sense cRNA probes were transcribed in vitro using a digoxigenin RNA labeling kit (Roche Applied Science).

As previously described (Ding et al. 2018), frozen sections $(10 \mu \mathrm{m})$ were mounted on 3-aminopropyltriethoxysilane (A3648; Sigma Aldrich)-treated slides and fixed in 4\% paraformaldehyde solution in PBS. Hybridization was performed at $55^{\circ} \mathrm{C}$ for $16 \mathrm{~h}$. Digoxigenin-labeled Fads 3 sense probe was used as negative control. Following hybridization and post-hybridization washes, sections were incubated with sheep anti-digoxigenin antibody conjugated to alkaline phosphatase (1:5000; Roche Applied Science). Endogenous alkaline phosphatase activity was inhibited with $2 \mathrm{mM}$ levamisole. All the sections were counterstained with $1 \%$ methyl green. The positive signal was visualized as a dark brown color.

\section{Isolation and culture of uterine stromal cells}

Mouse uterine stromal cells were isolated as described previously (Liang et al. 2014). Briefly, uterine horns from day 4 pregnant mice were split longitudinally, washed with Hanks' balanced salt solution (HBSS; Sigma) and digested with $1 \%(\mathrm{w} / \mathrm{v})$ trypsin (Amresco, Cleveland, USA) and $6 \mathrm{mg} /$ $\mathrm{mL}$ dispase (Roche Applied Science) in HBSS for $1 \mathrm{~h}$ at $4^{\circ} \mathrm{C}$ followed by $1 \mathrm{~h}$ at room temperature and $10 \mathrm{~min}$ at $37^{\circ} \mathrm{C}$. After rinsing three times with HBSS, the remaining tissues were incubated in $6 \mathrm{~mL}$ of HBSS containing $0.15 \mathrm{mg} / \mathrm{mL}$ collagenase I (Invitrogen; 17100-017) at $37^{\circ} \mathrm{C}$ for $30 \mathrm{~min}$. The digested tissues were shaken and filtered through a $70 \mu \mathrm{m}$ wire gauze filter and centrifuged to collect the stromal cells. The isolated cells were grown in DMEM/F-12 medium containing $2 \%$ heat-inactivated fetal bovine serum (FBS, Biological Industries, Cromwell, Israel). After an initial culture for $1 \mathrm{~h}$, the medium was changed to remove unattached epithelial cells. The stromal cells were cultured in DMEM/F-12 (D2906; Sigma Aldrich) containing 10\% (v/v) charcoal-stripped FBS (cFBS, Biological Industries). To induce in vitro decidualization, cells were treated with $10 \mathrm{nM}$ estrogen and $1 \mu \mathrm{M}$ progesterone in DMEM/F12 containing 2\% cFBS for different time points. 
Stromal cells were also treated with $1 \mu \mathrm{M}$ of progesterone for $24 \mathrm{~h}$. Cells were pretreated with $1 \mu \mathrm{M}$ of RU486 (Cayman) or JNK kinase inhibitor (Cayman) $1 \mathrm{~h}$ and then treated with progesterone.

\section{SiRNA transfection}

The siRNA for mouse Fads3 and nonspecific siRNA were designed and synthesized by Ribobio Co., Ltd. (Guangzhou, China). The stromal cells were transfected with siRNA using Lipofectamine 2000 (Invitrogen) according to the manufacturer's protocol. After cells were transfected for $6 \mathrm{~h}$, the stromal cells were induced for in vitro decidualization for $48 \mathrm{~h}$.

\section{Real-time PCR}

Total RNAs were extracted from the whole uteri or cultured cells by using TRIZOL (TaKaRa) and reverse transcribed into cDNA by following the PrimeScript reverse transcriptase reagent kit (TaKaRa). Then real-time PCR was performed with SYBR Premix Ex Taq kit (RR820A TaKaRa) on the CFX96 TOUCHTM (Bio-Rad). The specific primer sequences of each gene used for real-time were provided in Table 1 . The $2^{-\Delta \Delta \mathrm{Ct}}$ method was used to analyze the data from real-time PCR.

\section{Western blot analysis}

Western blot was performed as described previously (Liang et al. 2014). Briefly, proteins for Western blot were extracted from cultured stromal cells by homogenization lysis buffer including $50 \mathrm{mM}$ Tris- $\mathrm{HCl}, \mathrm{pH} 7.5,150 \mathrm{mM}$ $\mathrm{NaCl}, 1 \%$ Triton $\mathrm{X}-100$ and $0.25 \%$ sodium deoxycholate. The concentration of proteins was measured by BCA kit (Applygen, Beijing, China). The samples (10 $\mu$ g per lane) were separated by $10 \%$ SDS-PAGE gel and transferred onto PVDF membranes (Millipore) followed by blocking with 5\% non-flat milk (Sangon, Shanghai, China). PVDF membranes were probed with the corresponding antibodies for FADS3 (ABclonal,
Wuhan, China) and $\beta$-Actin (Cell Signaling) overnight at $4{ }^{\circ} \mathrm{C}$. Membranes were then incubated with the matched secondary antibodies conjugated with HRP (1:5000). Signals were detected with the ECL kit (Pierce Biotechnology).

\section{Statistical analysis}

All of the experiments were independently repeated at least three times. The difference between two groups was compared by Student's $t$ test. The multiple comparisons were performed with one-way ANOVA followed by Student's t-test. Data are presented as the mean \pm standard error. In all cases, $P<0.05$ was considered significantly different.

\section{Results}

\section{Fads1, Fads2 and Fads3 mRNA expression during early pregnancy}

In situ hybridization was used to examine the spatial distribution of Fads 1, Fads2 and Fads3 mRNA in mouse uteri during early pregnancy. There were no visible Fads 1 and Fads 2 mRNA signals in the uteri from days 1 to 4 of pregnancy. On day 5 of pregnancy, Fads 1 and Fads 2 mRNA signals were weakly detected in the subluminal stromal cells surrounding the implanting blastocyst at implantation sites. On days 6 and 8, Fads 1 and Fads 2 mRNA signals were faintly detected in the decidua (Fig. 1).

From days 1 to 4 of pregnancy, there was no visible Fads 3 mRNA signal in the uteri. On day 5 of pregnancy, Fads3 mRNA was detected specifically in the subluminal stromal cells surrounding the implanting blastocyst at implantation sites (Fig. 1). On days 6 and 8, Fads3 mRNA signals were highly detected in the decidua (Fig. 1).

Because the mRNA signals for Fads 1 and Fads2 were weakly detected in mouse uteri from days 1 to 8 of pregnancy, no further analysis was performed on Fads 1 and Fads2.

Table 1 Primers used in this study.

\begin{tabular}{|c|c|c|c|c|}
\hline Gene & ID & Primer sequences & Size $(b p)$ & Application \\
\hline Fads1 & BC063053 & $\begin{array}{l}\text { CTCTGGTTGGACGCTTAC } \\
\text { TGGAGAGTCAGATAGCCC }\end{array}$ & 364 & In situ hybridization \\
\hline Fads2 & ВС057189 & $\begin{array}{l}\text { CCACCTGTTCTTCTTTCTC } \\
\text { TGCAGGCTCTTTATGTCC }\end{array}$ & 324 & In situ hybridization \\
\hline Fads3 & ВC071266 & $\begin{array}{l}\text { ACAAGTGGCTGGTCATCG } \\
\text { CCAACAACTCCATAGCCAG }\end{array}$ & 339 & In situ hybridization \\
\hline Fads3 & NM-021890.3 & $\begin{array}{l}\text { CAGATACCTGCCCTACAACC } \\
\text { CCACAGCAAGTCCGTCCA }\end{array}$ & 132 & Real-time PCR \\
\hline Rp/7 & NM29016 & $\begin{array}{l}\text { GCAGATGTACCGCACTGAGATTC } \\
\text { ACCTTTGGGCTTACTCCATTGATA }\end{array}$ & 129 & Real-time PCR \\
\hline Dtprp & NM-010088 & $\begin{array}{l}\text { AGCCAGAAATCACTGCCACT } \\
\text { TGATCCATGCACCCATAAAA }\end{array}$ & 119 & Real-time PCR \\
\hline $\operatorname{Pr} / 3 c 1$ & NM_001163218 & $\begin{array}{l}\text { GGTTTGGCACATCTTGGTGTT } \\
\text { CACAGAACAAGGCCAAAGGC }\end{array}$ & 162 & Real-time PCR \\
\hline Вmp8a & NM_001256019.1 & $\begin{array}{l}\text { CGCCTCTATGTGGAAACCG } \\
\text { CTGGAGCGTGGTGCTTGTC }\end{array}$ & 82 & Real-time PCR \\
\hline Abp 1 & NM_001161621 & $\begin{array}{l}\text { GGTGAGCGTGTTGCCTAT } \\
\text { GGAAAGCATCCAGGAAAGT }\end{array}$ & 178 & Real-time PCR \\
\hline
\end{tabular}


Fads1
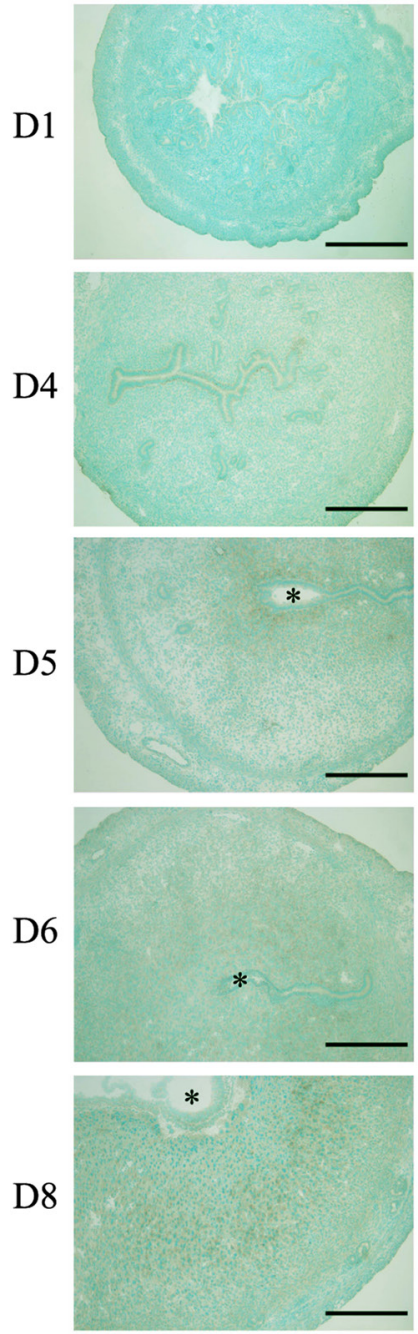

Fads2
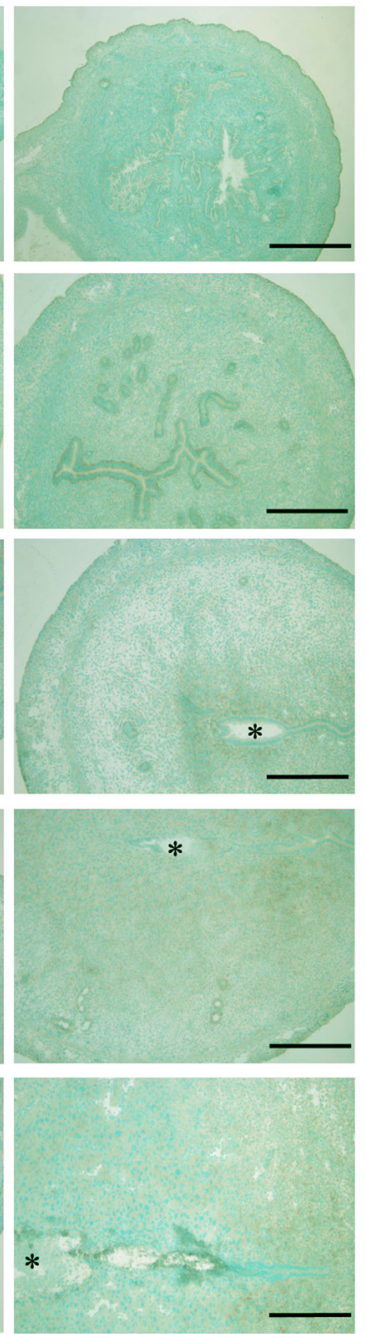

Fads3
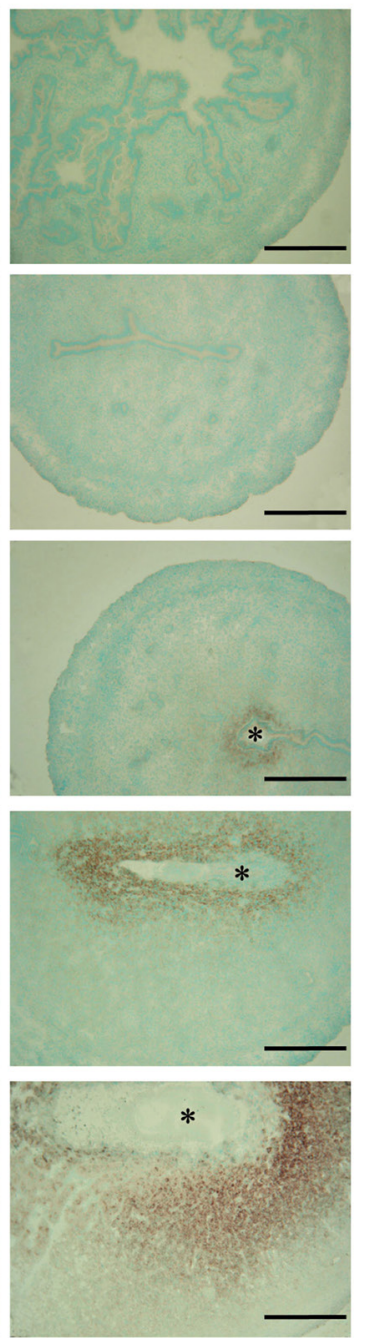

Figure 1 In situ hybridization of Fads1, Fads2 and Fads 3 mRNA in mouse uteri during early pregnancy, showing the localization of Fads1, Fads 2 and Fads 3 mRNA in mouse uteri on days 1 (D1), 4 (D4), 5 (D5), 6 (D6) and 8 (D8). On each day of pregnancy, 3-5 mice were used. At least three implantation sites per mouse were used for in situ hybridization and a representative section was shown. Asterisk (*), embryo. Bar $=300 \mu \mathrm{m}$.

\section{Fads3 mRNA expression during pseudopregnancy, delayed and activated implantation}

Because Fads3 was strongly detected at implantation sites, we also checked Fads3 expression at interimplantation sites. However, there was no detectable signal at inter-implantation sites (Fig. 2A). Data from RT-PCR also showed that Fads3 level at implantation site was significantly higher than that at inter-implantation sites on day 5 of pregnancy (Fig. 2B).

To further address whether the expression of Fads3 is dependent on the embryo, we examined the expression of Fads3 during pseudopregnancy. There was no detectable Fads 3 signal in mouse uteri on day 5 of pseudopregnancy (Fig. 2A).

Delayed implantation model was applied to assess whether Fads3 expression is regulated by active blastocyst. When embryo implantation was delayed by ovariectomy, there was no detectable Fads3 mRNA signal in the uteri. After delayed implantation was terminated by estrogen, Fads3 mRNA was detected in the subluminal stromal surrounding the blastocyst of implantation sites (Fig. 2A).

\section{Fads3 mRNA expression during artificial decidualization}

Because Fads3 expression was strongly detected in the decidua on day 8 of pregnancy, RT-PCR was used to verify Fads 3 expression. Compared to inter-implantation site, Fads3 expression level was significantly higher at implantation sites on day 8 of pregnancy (Fig. 3A). Then, artificial decidualization model was used to determine whether Fads3 is induced by oil injection. There was no detectable Fads3 mRNA signal in the control uterine horn, while a high level of Fads 3 mRNA expression was detected in the deciduoma of oil-injected uterine horn (Fig. 3B). Real-time PCR results also showed that Fads3 mRNA signals were strongly upregulated in deciduoma compared with control (Fig. 3C). 
A

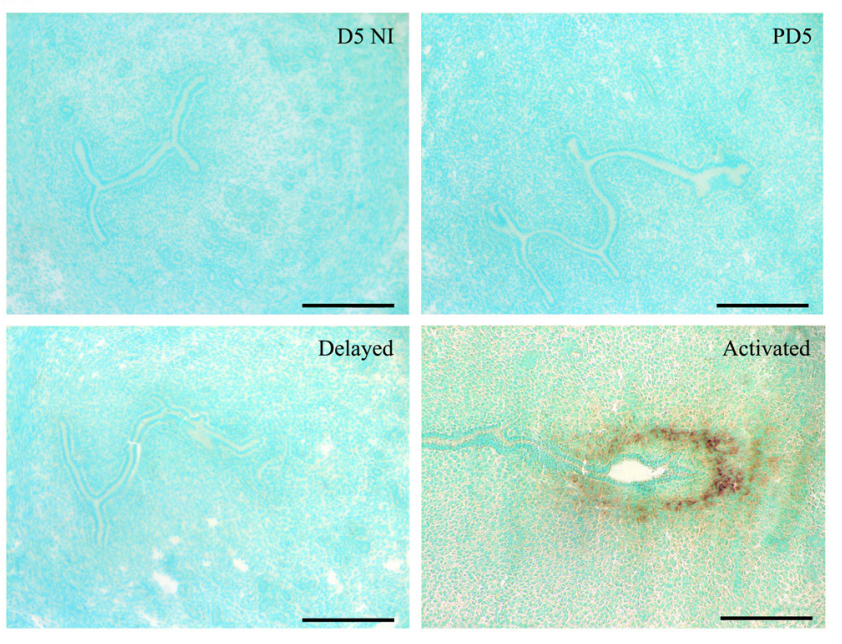

$\mathrm{B}$

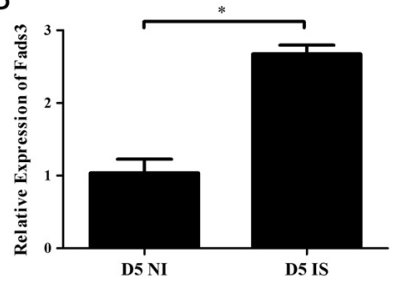

Figure 2 Expression of Fads 3 mRNA during pseudopregnancy and under delayed implantation. (A) In situ hybridization of Fads3 expression at inter-implantation site on day 5 of pregnancy (D5 NI), on day 5 of pseudopregnancy and under delayed implantation and activated uteri. D5 NI, inter-implantation site on day 5; PD5, day 5 of pseudopregnancy; Asterisk (*), embryo. Bar $=300 \mu \mathrm{m}$. Three mice were used in each group. At least 3-5 sections from each mouse were used for in situ hybridization. A representative section was shown. (B) Real-time PCR analysis of Fads3 expression between inter-implantation and implantation on day 5. D5 IS, implantation site on day 5. Uteri from three mice were used for real-time PCR. Three independent repeats were performed.

\section{Steroid hormonal regulation on Fads3}

Because estrogen and progesterone are crucial for mouse decidualization (Dey et al. 2004), ovariectomized mice were used to determine whether Fads3 expression was regulated by estrogen and progesterone. After ovariectomized mice were treated with estrogen, Fads3 expression was weakly detected in the luminal epithelium and stromal cells compared with control (Fig. 4A). Real-time PCR analysis showed that Fads3 mRNA level was remarkably enhanced compared with control uteri. However, estrogen had no stimulating effect on Fads3 expression in ovariectomized ER $\alpha$ knockout mice (Fig. 4B), suggesting that estrogen regulation of Fads3 expression is ER $\alpha$-dependent.

When ovariectomized mice were treated with progesterone, Fads3 mRNA signals were weakly seen in uterine luminal epithelium and stromal cells (Fig. 4A). Data from real-time PCR indicated that Fads3 expression was significantly increased compared with
A

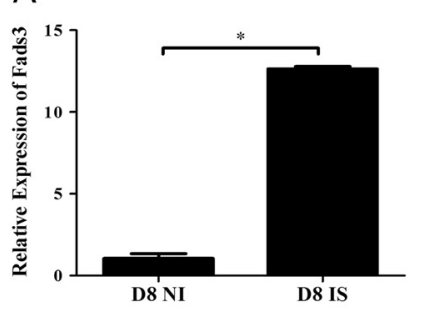

C

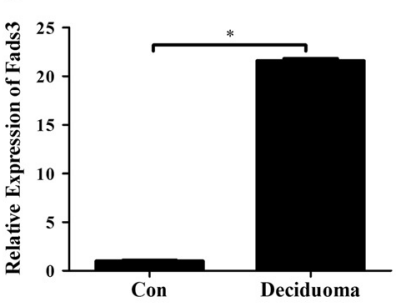

B
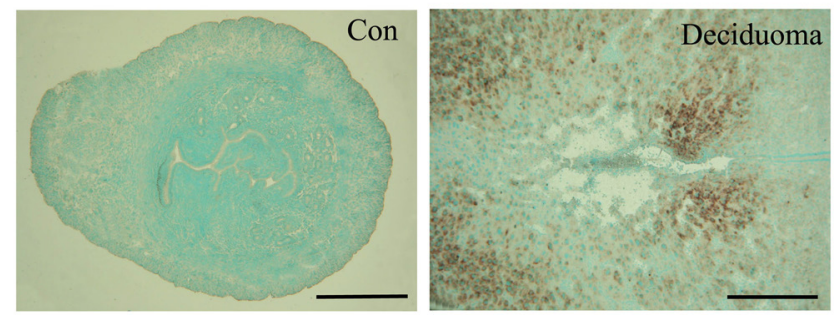

Figure 3 Expression of Fads 3 mRNA during artificial decidualization. (A) Real-time PCR analysis of Fads3 expression between interimplantation and implantation on day 8. D8-NI, inter-implantation site on day 8; D8-IS, implantation site on day 8. (B) In situ hybridization of Fads3 expression under artificial decidualization. Bar $=300 \mu \mathrm{m}$. (C) Real-time PCR analysis of Fads3 expression under artificial decidualization. Uteri from three mice were used for real-time PCR. Three independent repeats were performed. At least 3-5 sections from each mouse were used for in situ hybridization. A representative section was shown.

control (Fig. 4C). Furthermore, Fads3 expression was also obviously increased when cultured stromal cells were treated with progesterone, which was abrogated by RU486 treatment (Fig. 4D), suggesting that progesterone regulation of Fads3 expression is progesterone receptor dependent. In the cultured stromal cells, the expression of Fads3 was inhibited by JNK kinase inhibitor, and progesterone induction on Fads3 expression was slightly inhibited by the inhibitor for JNK kinase (Fig. 4E).

\section{Fads3 $m R N A$ expression during in vitro decidualization}

Because Fads3 is strongly expressed in the decidual cells, in vitro decidualization model was used to examine whether Fads3 is involved in mouse decidualization. After stromal cells were induced for in vitro decidualization, there was a significant induction of Dtprp, Prl3c1 and Bmp8a (Fig. 5), reliable markers for mouse in vitro decidualization (Kimura et al. 2001, Bany \& Cross 2006, Kelleher et al. 2017, Li et al. 2017). Meanwhile, Fads3 expression was also significantly induced under in vitro decidualization for 12, 24, 48 and $72 \mathrm{~h}$, respectively (Fig. 5B).

To investigate the function of Fads3 during decidualization, the expression of Fads 3 was silenced by the specific siRNA. After Fads3 expression was knocked down by Fads3 siRNA (Fig. 5C and D), there was a remarkable reduction for the expression levels of Dtprp, 


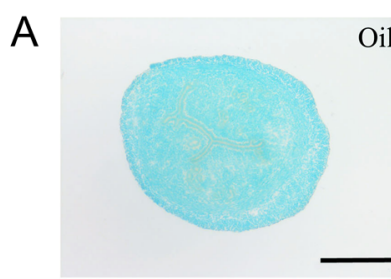

Oil

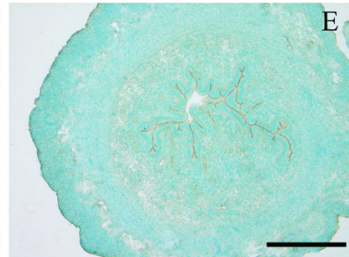

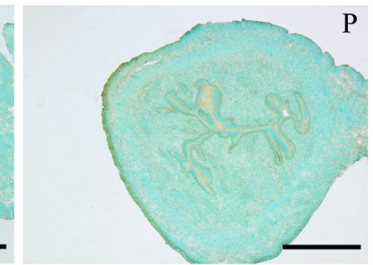

B
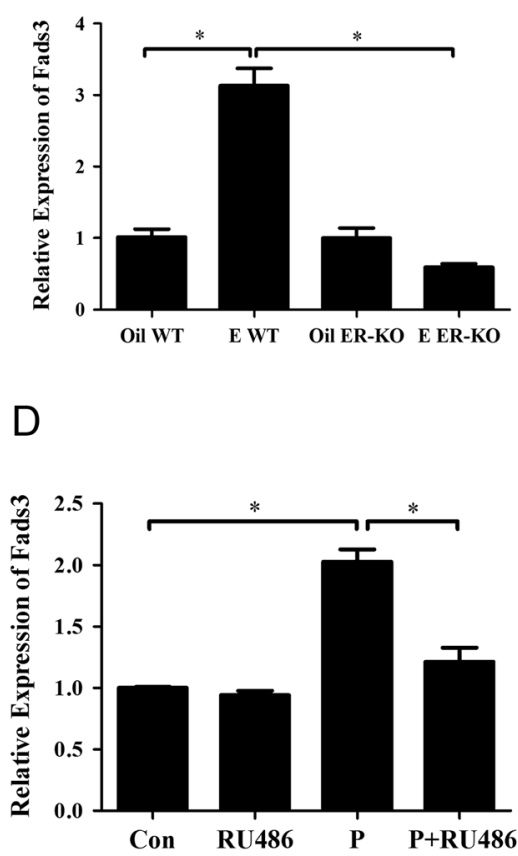

C

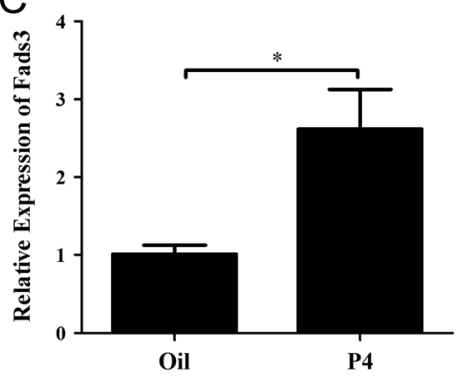

E

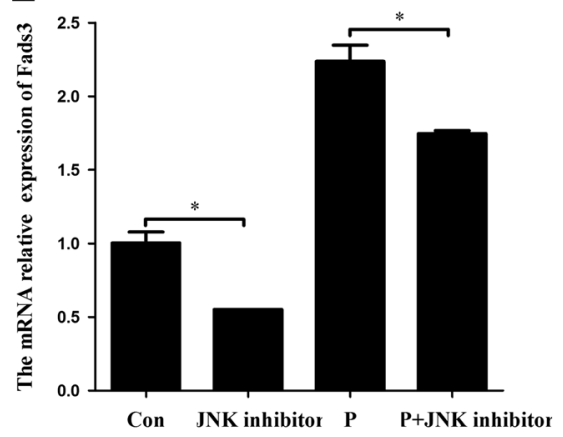

Figure 4 Steroid hormones regulation on Fads3 mRNA expression. (A) In situ hybridization of Fads3 expression after ovariectomized mice were treated with sesame oil, estrogen and progesterone, respectively. (B) Real-time PCR of Fads 3 mRNA expression after WT or ER KO ovariectomized mice were injected with estrogen. (C) Real-time PCR of Fads3 mRNA expression after WT ovariectomized mice were injected with progesterone. (D) Real-time PCR of Fads3 mRNA expression after stromal cells were treated with progesterone or progesterone plus RU486. Con, control; E, estrogen; P, progesterone; group P+RU486. Co-treatment with progesterone plus RU486. (E) Effects of JNK inhibitor on progesteroneinduced Fads 3 expression. Stromal cells were pretreated with JNK inhibitor for $1 \mathrm{~h}$ and then treated with progesterone. Three mice were used in each group. At least 3-5 sections from each mouse were used for in situ

hybridization. A representative section was shown. All experiments were repeated at least three times.
Prl3c1 and Bmp8a (Fig. 5E, F and G). Meanwhile, based on in situ hybridization, Fads3 shares a co-localization with $A b p 1$, which is essential to mouse embryo implantation and decidualization (Liang et al. 2010). In this study, Abp 1 expression was remarkably reduced following Fads3 siRNA treatment (Fig. 5H).

Of the prostaglandins synthesized from arachidonic acid, PGE2 has been proved to be essential to decidualization (Kennedy et al. 2007). When stromal cells were treated with PGE2 under in vitro decidualization, PGE2 had no obvious effects on Fads3 expression (Fig. 6A). Although PGE2 had no stimulating effects on both Dtprp and Prl3c1 levels, PGE2 was able to rescue the inhibitory effect of Fads 3 siRNA on both Dtprp and Pr/3c1 levels (Fig. 6B and C).

\section{Discussion}

In this study, we showed that Fads3 is strongly expressed in the decidual cells at implantation sites. Furthermore, Fads3 expression is not detected at inter-implantation sites, in day 5 pseudopregnant uterus and under delayed uterus, suggesting that Fads3 expression is embryo dependent during peri-implantation period.
Under in vitro decidualization, knockdown of Fads3 expression by siRNA leads to a significantly reduction of Dtprp, Bmp8a and Prl3c1, which are reliable markers for mouse in vitro decidualization (Kimura et al. 2001, Bany \& Cross 2006, Kelleher et al. 2017, Li et al. 2017). These data suggest that Fads3 may play a role during mouse decidualization. Based on the high homology with FADS1 and FADS2, FADS3 should be important for arachidonic acid (Pedrono et al. 2010). Our previous study showed that arachidonic acid can activate the cytosolic phospholipase A2a (CPLA2a)/ cyclooxygenase-2 (COX2) pathway, which is essential during embryo implantation and decidualization in mouse uterus (Zhao et al. 2012). cPLA2a catalyzes arachidonic acid release from membrane phospholipids (Murakami et al. 2000). cPLA2a is crucial for successful pregnancy because of CPLA2a KO mice show small litters, abnormal uterine spacing of embryos and often exhibit pregnancy failures (Bonventre et al. 1997, Song et al. 2002). Conditional deletion of mouse uterine Trp53 (p53(d/d)), leads to premature uterine senescence and preterm birth, and also causes an increase in arachidonic and docosahexaenoic acid (Lanekoff et al. 2016). These data suggest that a balance in arachidonic acid should be essential for decidual development. It is 
A
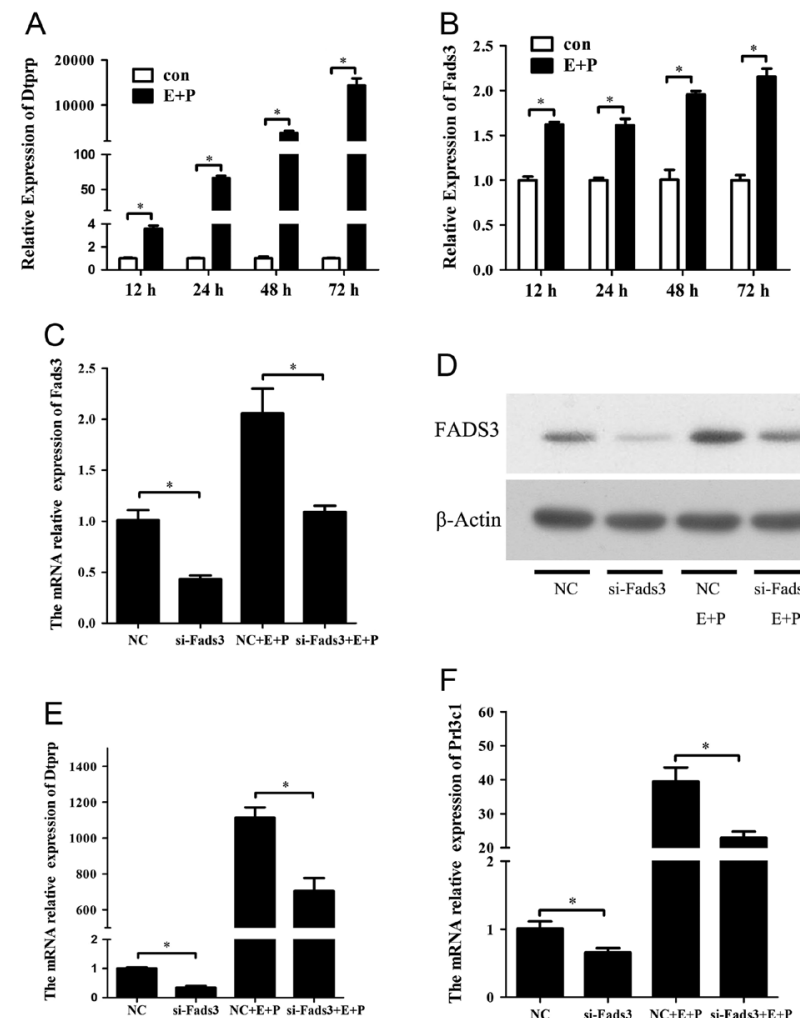

G

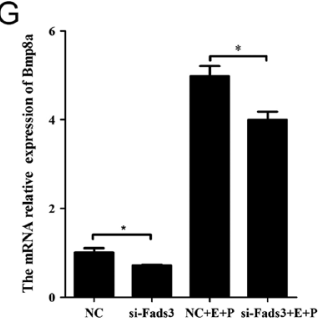

$\mathrm{D}$

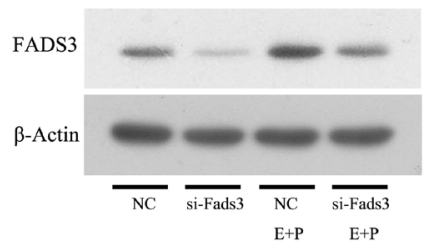

$\mathrm{F}$

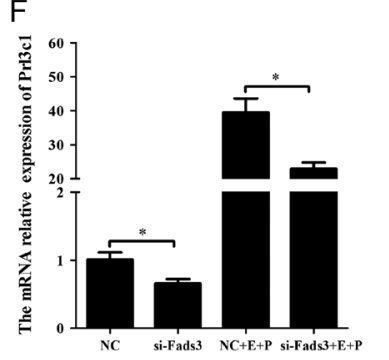

$\mathrm{H}$

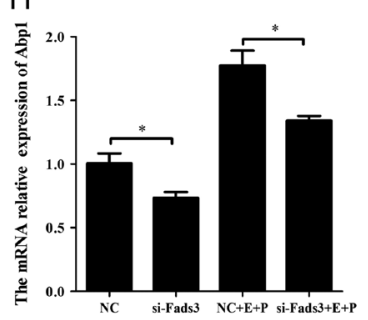

Figure 5 Expression and function of Fads3 under in vitro decidualization. (A) Real-time PCR of Dtprp mRNA expression under in vitro decidualization from $12 \mathrm{~h}$ to $72 \mathrm{~h}$. (B) Real-time PCR of Fads 3 mRNA expression during in vitro decidualization. Fads3 expression was obviously upregulated compared to the control from $12 \mathrm{~h}$ to 72 h. (C) Fads3 mRNA expression after stromal cells were transfected with Fads3 siRNA and the nonspecific siRNA (NC) under in vitro decidualization for $48 \mathrm{~h}$. (D) Western blot analysis showed that FADS3 protein level was significantly reduced by Fads3 siRNA. (E) Effects of Fads3 siRNA on Dtprp expression. (F) Effects of Fads3 siRNA on Prl3c1 expression. (G) Effects of Fads3 siRNA on Bmp8a expression. (H) Effects of Fads3 siRNA on Abp 1 expression. Con, control; group $\mathrm{E}+\mathrm{P}$, Co-treatment with estrogen plus progesterone. Stromal cells from 3 to 6 mice were isolated, pooled and used for cell culture and treatments in triplicates. All experiments were repeated at least three times.

possible that Fads 3 is involved in mouse decidualization through arachidonic acid production.

Furthermore, arachidonic acid can be converted to prostaglandin $\mathrm{H} 2(\mathrm{PGH} 2)$ by $\mathrm{COX} 2$, a crucial ratelimiting enzyme. COX2-null mice resulted infertility with multiple defects in ovulation, embryo implantation

and decidualization in female reproduction. These defects can be restored by exogenous prostaglandin administration in both of cPLA2a- and COX2-null mice (Lim et al. 1997, Song et al. 2002). Indomethacin, an inhibitor of COX2, can suppress the generation of PGE2 and result in embryo implantation failure (Hamilton \& Kennedy 1994). PGE2 is essential to decidualization (Kennedy et al. 2007). In this study, PGE2 is able to rescue the inhibitory effect of Fads3 siRNA on both Dtprp and Prl3c1 levels although PGE2 has no stimulating effect on Fads3 expression, suggesting that Fads3 may be involved in PGE2 synthesis. Additionally, our previous study reported that Abp1 mRNA is highly expressed in the decidual cells in mouse uterus and plays a role during mouse decidualization (Liang et al. 2010). Based on data from in situ hybridization, Fads3 is co-localized with $A b p 1$ in the primary decidual zone in mouse uterus, suggesting that Fads3 may have a connection with Abp 1 during mouse decidualization. In this study, knockdown of Fads3 expression by siRNA leads to a significant reduction on $A b p 1$ expression during in vitro decidualization, suggesting that Fads3 may regulate mouse decidualization through $A b p 1$.

In our study, the levels of Dtprp, Prl3c1 and Bamp8 are partially inhibited by Fads3 siRNA. The failure of complete inhibition of decidualization may be caused by the partial inhibition of Fads3 siRNA on Fads3 expression and the possible involvement of both Fads 1 and Fads2. Both Fads 1 and Fads 2 are also weakly expressed in the primary decidual zone on day 5 of pregnancy. It is known that FADS1 and FADS2 participate in the biosynthesis of arachidonic acid from LA (Hester et al. 2014). However, the molecular mechanism of Fads3 action needs to be further explored.

Estrogen is crucial for blastocyst implantation in rodents (Zhang et al. 2013). Conditional knockout $E R \alpha$ in mouse uteri results in implantation failure (Mulac-Jericevic et al. 2000). Our study showed that Fads3 expression level was significantly higher after ovariectomized mice were treated with estrogen. However, estrogen has no effects on Fads3 expression in ERo-deficient ovariectomized mice, suggesting that estrogen regulates Fads3 expression via ER $\alpha$ in mouse uteri.

In this study, progesterone stimulated Fads3 expression in ovariectomized mouse uterus and cultured uterine stromal cells, which was abrogated by progesterone receptor antagonist RU486. These results indicate that progesterone stimulates Fads 3 expression through PR. Recent studies showed that Fads3 is a target gene for MYCN, NF-kB or p63 transcription factors, which could be involved in cell proliferation, differentiation and apoptosis (Yan et al. 2007, Gu et al. 2008). Decidualization is characterized by stromal cells proliferation, differentiation and apoptosis. Furthermore, within the mouse mammary gland, NF- $\mathrm{kB}$ is upregulated by progesterone. NF- $\mathrm{\kappa B}$ is also a regulator of COX2 
A

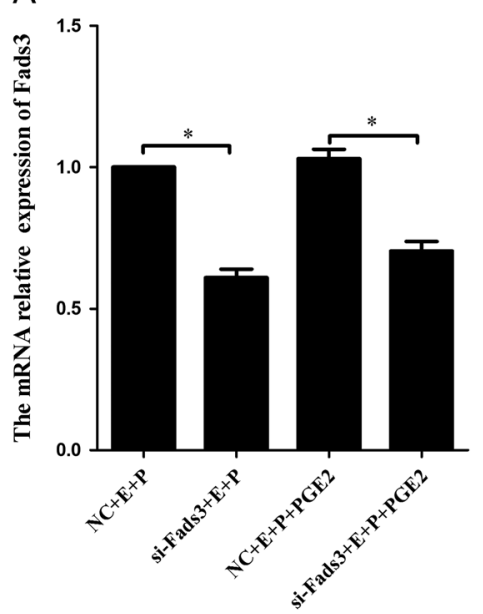

B

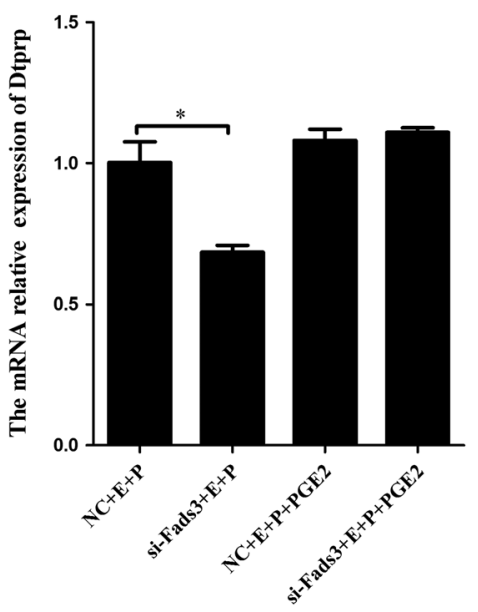

C

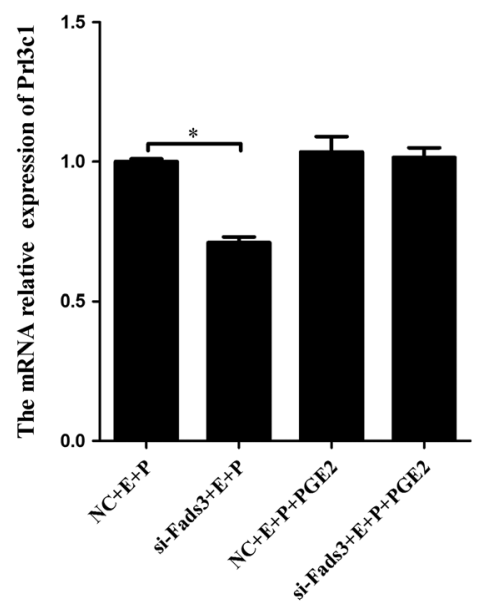

Figure 6 Effects of PGE2 on Fads3 action during in vitro decidualization. (A) PGE2 has no effects on Fads3 expression. (B) PGE2 has no stimulating effects on Dtprp, but can rescue the inhibitory effect of Fads3 siRNA on Dtprp level. (C) PGE2 has no stimulating effects on Dtprp, but can rescue the inhibitory effect of Fads 3 siRNA on Pr/3c1. Stromal cells from 3 to 6 mice were isolated, pooled and used for cell culture and treatments in triplicates. All experiments were repeated at least three times.

expression in many cell types (Schmedtje et al. 1997). It is possible that progesterone may regulate Fads3 through NF-KB. We also showed that JNK-1 may be involved in progesterone regulation on Fads3 because progesterone induction of Fads3 is decreased by JNK-1 inhibitor.

In conclusion, Fads3 is strongly expressed in the decidual cells and regulated by estrogen or progesterone. Knockdown of Fads3 can reduce decidualization.

\section{Declaration of interest}

The authors declare that there is no conflict of interest that could be perceived as prejudicing the impartiality of the research reported.

\section{Funding}

This work was supported by National Natural Science Foundation of China (31471397, 31272263 and 31671563).

\section{References}

Bany BM \& Cross JC 2006 Post-implantation mouse conceptuses produce paracrine signals that regulate the uterine endometrium undergoing decidualization. Developments in Biologicals 294 445-456. (https://doi. org/10.1016/j.ydbio.2006.03.006)

Blanchard H, Legrand P \& Pedrono F 2011 Fatty acid desaturase 3 (Fads3) is a singular member of the Fads cluster. Biochimie 93 87-90. (https:// doi.org/10.1016/j.biochi.2010.03.002)

Bonventre JV, Huang Z, Taheri MR, O'Leary E, Li E, Moskowitz MA \& Sapirstein A 1997 Reduced fertility and postischaemic brain injury in mice deficient in cytosolic phospholipase A2. Nature 390 622-625. (https://doi.org/10.1038/37635)

Carson DD, Bagchi I, Dey SK, Enders AC, Fazleabas AT, Lessey BA \& Yoshinaga K 2000 Embryo implantation. Developments in Biologicals 223 217-237. (https://doi.org/10.1006/dbio.2000.9767)
Dey SK, Lim H, Das SK, Reese J, Paria BC, Daikoku T \& Wang H 2004 Molecular cues to implantation. Endocrine Reviews 25 341-373. (https:// doi.org/10.1210/er.2003-0020)

Ding NZ, Qi QR, Gu XW, Zuo RJ, Liu J \& Yang ZM 2018 De novo synthesis of sphingolipids is essential for decidualization in mice. Theriogenology 106 227-236. (https://doi.org/10.1016/j.theriogenology.2017.09.036)

Gellersen B \& Brosens JJ 2014 Cyclic decidualization of the human endometrium in reproductive health and failure. Endocrine Reviews 35 851-905. (https://doi.org/10.1210/er.2014-1045)

Gu X, Coates PJ, Boldrup L \& Nylander K 2008 p63 contributes to cell invasion and migration in squamous cell carcinoma of the head and neck. Cancer Letters 263 26-34. (https://doi.org/10.1016/j. canlet.2007.12.011)

Hamilton GS \& Kennedy TG 1994 Uterine vascular changes after unilateral intrauterine infusion of indomethacin and prostaglandin E2 to rats sensitized for the decidual cell reaction. Biology of Reproduction $\mathbf{5 0}$ 757-764. (https://doi.org/10.1095/biolreprod50.4.757)

Hester AG, Murphy RC, Uhlson CJ, Ivester P, Lee TC, Sergeant S, Miller LR, Howard TD, Mathias RA \& Chilton FH 2014 Relationship between a common variant in the fatty acid desaturase (FADS) cluster and eicosanoid generation in humans. Journal of Biological Chemistry 289 22482-22489. (https://doi.org/10.1074/jbc.M114.579557)

Kelleher AM, Peng W, Pru JK, Pru CA, DeMayo FJ \& Spencer TE 2017 Forkhead box a2 (FOXA2) is essential for uterine function and fertility. PNAS 114 E1018-E1026. (https://doi.org/10.1073/pnas.1618433114)

Kennedy TG, Gillio-Meina C \& Phang SH 2007 Prostaglandins and the initiation of blastocyst implantation and decidualization. Reproduction 134 635-643. (https://doi.org/10.1530/REP-07-0328)

Kimura F, Takakura K, Takebayashi K, Ishikawa H, Kasahara K, Goto S \& Noda Y 2001 Messenger ribonucleic acid for the mouse decidual prolactin is present and induced during in vitro decidualization of endometrial stromal cells. Gynecological Endocrinology 15 426-432. (https://doi.org/10.1080/713602980)

Kothapalli KS, Ye K, Gadgil MS, Carlson SE, O'Brien KO, Zhang JY, Park HG, Ojukwu K, Zou J, Hyon SS et al. 2016 Positive selection on a regulatory insertion-deletion polymorphism in FADS2 influences apparent endogenous synthesis of arachidonic acid. Molecular Biology Evolution 33 1726-1739. (https://doi.org/10.1093/molbev/msw049)

Lanekoff I, Cha J, Kyle JE, Dey SK, Laskin J \& Burnum-Johnson KE 2016 Trp53 deficient mice predisposed to preterm birth display region-specific lipid alterations at the embryo implantation site. Scientific Reports 6 33023. (https://doi.org/10.1038/srep33023) 
Lee JM, Lee H, Kang S \& Park WJ 2016 Fatty acid desaturases, polyunsaturated fatty acid regulation, and biotechnological advances. Nutrients 8 23. (https://doi.org/10.3390/nu8010023)

Li DD, Yue L, Yang ZQ, Zheng LW \& Guo B 2017 Evidence for Hmgn2 involvement in mouse embryo implantation and decidualization. Cellular Physiology and Biochemistry 44 1681-1695. (https://doi. org/10.1159/000485775)

Liang XH, Zhao ZA, Deng WB, Tian Z, Lei W, Xu X, Zhang XH, Su RW \& Yang ZM 2010 Estrogen regulates amiloride-binding protein 1 through CCAAT/enhancer-binding protein-beta in mouse uterus during embryo implantation and decidualization. Endocrinology 151 5007-5016. (https://doi.org/10.1210/en.2010-0170)

Liang XH, Deng WB, Li M, Zhao ZA, Wang TS, Feng XH, Cao YJ, Duan EK \& Yang ZM 2014 Egr1 protein acts downstream of estrogenleukemia inhibitory factor (LIF)-STAT3 pathway and plays a role during implantation through targeting Wnt4. Journal of Biological Chemistry 289 23534-23545. (https://doi.org/10.1074/jbc.M114.588897)

Lim H, Paria BC, Das SK, Dinchuk JE, Langenbach R, Trzaskos JM \& Dey SK 1997 Multiple female reproductive failures in cyclooxygenase 2-deficient mice. Cell 91 197-208. (https://doi.org/10.1016/S00928674(00)80402-X)

Ma XH, Hu SJ, Ni H, Zhao YC, Tian Z, Liu JL, Ren G, Liang XH, Yu H, Wan P et al. 2006 Serial analysis of gene expression in mouse uterus at the implantation site. Journal of Biological Chemistry 281 9351-9360. (https://doi.org/10.1074/jbc.M511512200)

Mulac-Jericevic B, Mullinax RA, DeMayo FJ, Lydon JP \& Conneely OM 2000 Subgroup of reproductive functions of progesterone mediated by progesterone receptor-B isoform. Science 289 1751-1754. (https://doi. org/10.1126/science.289.5485.1751)

Murakami M, Nakatani Y, Kuwata H \& Kudo I 2000 Cellular components that functionally interact with signaling phospholipase $\mathrm{A}(2) \mathrm{s}$. Biochimica et Biophysica Acta 1488 159-166. (https://doi.org/10.1016/S13881981(00)00118-9)

Nakamura MT \& Nara TY 2004 Structure, function, and dietary regulation of delta6, delta5, and delta9 desaturases. Annual Review of Nutrition 24 345-376. (https://doi.org/10.1146/annurev.nutr.24.121803.063211)

Park HG, Kothapalli KSD, Park WJ, DeAllie C, Liu L, Liang A, Lawrence P \& Brenna JT 2016 Palmitic acid (16:0) competes with omega-6 linoleic and omega, vol 3 A-linolenic acids for FADS2 mediated Delta6-desaturation. Biochimica et Biophysica Acta 1861 91-97. (https://doi.org/10.1016/j. bbalip.2015.11.007)

Pedrono F, Blanchard H, Kloareg M, D'Andrea S, Daval S, Rioux V \& Legrand P 2010 The fatty acid desaturase 3 gene encodes for different
FADS3 protein isoforms in mammalian tissues. Journal of Lipid Research 51 472-479. (https://doi.org/10.1194/jlr.M000588)

Schmedtje JF Jr, Ji YS, Liu WL, DuBois RN \& Runge MS 1997 Hypoxia induces cyclooxygenase-2 via the NF-kappaB p65 transcription factor in human vascular endothelial cells. Journal of Biological Chemistry 272 601-608. (https://doi.org/10.1074/jbc.272.1.601)

Schomberg DW, Couse JF, Mukherjee A, Lubahn DB, Sar M, Mayo KE \& Korach KS 1999 Targeted disruption of the estrogen receptor-alpha gene in female mice: characterization of ovarian responses and phenotype in the adult. Endocrinology 140 2733-2744. (https://doi.org/10.1210/ endo.140.6.6823)

Song H, Lim H, Paria BC, Matsumoto H, Swift LL, Morrow J, Bonventre JV \& Dey SK 2002 Cytosolic phospholipase A2alpha is crucial (correction of A2alpha deficiency is crucial) for 'on-time' embryo implantation that directs subsequent development. Development 129 2879-2889.

Yan B, Yang X, Lee TL, Friedman J, Tang J, Van Waes C \& Chen Z 2007 Genome-wide identification of novel expression signatures reveal distinct patterns and prevalence of binding motifs for p53, nuclear factor-kappaB and other signal transcription factors in head and neck squamous cell carcinoma. Genome Biology 8 R78. (https://doi.org/10.1186/gb-20078-5-r78)

Zhang S, Lin H, Kong S, Wang S, Wang H, Wang H \& Armant DR 2013 Physiological and molecular determinants of embryo implantation. Molecular Aspects of Medicine 34 939-980. (https://doi.org/10.1016/j. mam.2012.12.011)

Zhang JY, Qin X, Liang A, Kim E, Lawrence P, Park WJ, Kothapalli KSD \& Brenna JT 2017 Fads3 modulates docosahexaenoic acid in liver and brain. Prostaglandins, Leukotrienes, and Essential Fatty Acids 123 25-32. (https://doi.org/10.1016/j.plefa.2017.07.001)

Zhao ZA, Zhang ZR, Xu X, Deng WB, Li M, Leng JY, Liang XH \& Yang ZM 2012 Arachidonic acid regulation of the cytosolic phospholipase A 2alpha/cyclooxygenase-2 pathway in mouse endometrial stromal cells. Fertility and Sterility 97 1199-1205. (https://doi.org/10.1016/j. fertnstert.2012.02.011)

Received 15 March 2018

First decision 9 April 2018

Revised manuscript received 9 August 2018

Accepted 9 August 2018 